\title{
Toxicology of skin of Rana catesbeiana as a biological dressing in skin wounds of rats
}

\section{Toxicologia da pele de Rana catesbeiana como um curativo biológico de feridas da pele de ratos.}

João Pedro Santiago Paiva Marques ${ }^{1}$, Ítalo Medeiros Azevedo ${ }^{2}$, Aldo Cunha Medeiros ${ }^{3}$

1. Graduate student, Medical School, Federal University of Rio Grande do Norte (UFRN), Natal-RN, Brazil.

2. Fellow PhD degree, Postgraduate Program in Health Sciences, UFRN, Natal-RN, Brazil.

3. PhD, Full Professor, Chairman, Nucleus of Experimental Surgery, UFRN, Natal-RN, Brazil.

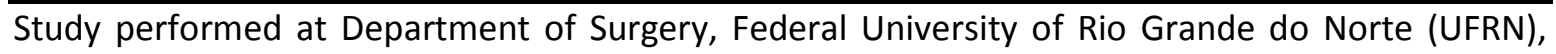
Brazil.

Financial support: None.

Conflict of interest: The authors declare that they have no conflict of interest.

Correspondence address: Department of Surgery, Federal University of Rio Grande do Norte, at Ave. Nilo Peçanha 620, Natal, RN, Brazil. E-mail: cirurgex.ufrn@gmail.com

Submitted: July 6, 2018. Accepted, after review: August 14, 2018.

\section{ABSTRACT}

Purpose: The aim of this study was to evaluated the toxicity in rats' kidney and liver by using Rana catesbeiana's skin as biological dressing in skin wounds. Methods: Twenty Wistar rats were used; in all rats a back dorsum skin segment with $4 \mathrm{~cm}^{2}$ was removed under anesthesia and aseptic technique. In group $A(n=10)$ the wounds were treated with frog's skin as a biological dressing. In group $B(n=10)$ the wounds were treated with $1 \mathrm{~mL}$ of $0,9 \%$ saline solution. After 15 days, blood was collected for dosing serum AST, ALT, urea and creatinine. Results: Biochemical dosages evaluated liver and renal function tests. The values of AST, ALT, urea and creatinine showed no significant difference when the test and control groups were compared ( $p>0.05$ ). Conclusion: The use of Rana catesbeiana's skin as a biological dressing of rats wounds did not show toxic effects for liver and kidney functions.

Key words: Biological dressings. Rana catesbeiana. Toxicology. 


\section{RESUMO}

Objetivo: O objetivo deste estudo foi avaliar a toxicidade da pele de Rana catesbeiana como curativo biológico em feridas cutâneas, para o rim e fígado de ratos. Métodos: Foram utilizados 20 ratos Wistar; em todos eles foi removido um segmento da pele dorsal com $4 \mathrm{~cm}^{2}$, sob anestesia e técnica asséptica. No grupo $A(n=10)$ as feridas foram tratadas com pele de rã como curativo biológico. No grupo $B(n=10)$ as feridas foram tratadas com $1 \mathrm{~mL}$ de solução salina a 0,9\%. Após 15 dias, o sangue foi coletado para dosagem sérica de AST, ALT, uréia e creatinina. Resultados: As dosagens bioquímicas avaliaram testes de função hepática e renal. Os valores de AST, ALT, uréia e creatinina não apresentaram diferença significativa quando comparados os grupos teste e controle $(p>0,05)$. Conclusão: $\mathrm{O}$ uso da pele de Rana catesbeiana como curativo biológico de feridas da pele de ratos não mostrou efeitos tóxicos para as funções hepática e renal.

Descritores: Curativo biológico. Rana catesbeiana. Toxicologia. Ratos.

\section{INTRODUCTION}

Frog skin is a rich source of biologically active peptides ${ }^{1}$ present in large amounts in some species. Many of these peptides have antimicrobial activities, reaching a broad spectrum against Gram negative and positive bacteria, fungi and protozoa. Mucous glands of frogs play a role in moisture maintenance and also have bacteriostatic properties. Amphibian granular gland is a place for the production of wide spectrum of chemical compounds, including amines, alkaloids, steroids and peptides, that have vital role in protection against bacteria and fungi².

Antimicrobial effects of frog skin peptides have been also documented ${ }^{2}$. Two peptides named Temporin-Ra and Temporin-Rb have been isolated from skin frog secretions by HPLC method ${ }^{1}$.

Acceleration of wound healing by the application of several biological membranes is very common owing to their efficacy in preventing infection and sepsis. However, frog skin plays a complex role in addition to helping in the haemostasis and mechanical protection to wound site $\mathrm{s}^{3}$. Hence the purification and characterization of the individual 
constituents of the frog skin and understanding the mechanism of biological activity has been attempted in a sequential manner. Four broad spectrum and residue novel antimicrobial peptides coined tigerinins have been isolated ${ }^{4}$.

Since the amphibians skin is rich in a large number of peptides, it is important to study the effect of this skin at the systemic level, specifically its consequences on kidney and liver functions, to ensure that its use will not cause any toxic effects to vital organs. In addition, predict the feasibility of use in humans to improve the treatment of open wounds, reducing healing time, tissue injury and treatment cost ${ }^{5}$. Open skin wounds, which heal by second intention, have delayed healing and infection as frequent postoperative disturbs. Despite the use of prophylactic antibiotics, antisepsis and the technical progress of surgery, wound infection continues to be a serious complication, prolonging convalescence, increasing hospital costs, causing discomfort to patients and eventually progressing to death ${ }^{6}$. In addition to postoperative surgical infection, skin ulcers often occur, especially those resulting from diabetes and varicose veins of the lower limbs. These ulcers are characterized by chronicity and difficult cure, so that various topical and systemic treatments have been tried and tested ${ }^{6}$.

Taking into account these data, the present work had the objective of evaluating the toxicity to kidney and liver functions of the skin of Rana catesbiana as biological dressing, used on skin wounds of rats.

\section{METHODS}

Twenty Wistar rats were randomly divided into two groups of 10 animals. The study was approved by the institutional Ethics Comission on the Use of Animals (CEUA/HUOL), protocol number 02/2016 and all the procedures were done according to the Brazilian Law $n^{\circ} 11.794 / 2008$.

The rats were anesthetized with ketamine $70 \mathrm{mg} / \mathrm{kg}$ weight associated with xylazine $7 \mathrm{mg} / \mathrm{kg}$, intraperitoneally (i.p.). They were operated with aseptic technique and observed in individual cages with water and food ad libitum. In all animals, a $4 \mathrm{~cm}^{2}$ 
segment of skin was removed from the dorsum (Figure 1), by using a mold with the same dimension (Figure 2), followed by topical treatment of the wounds.

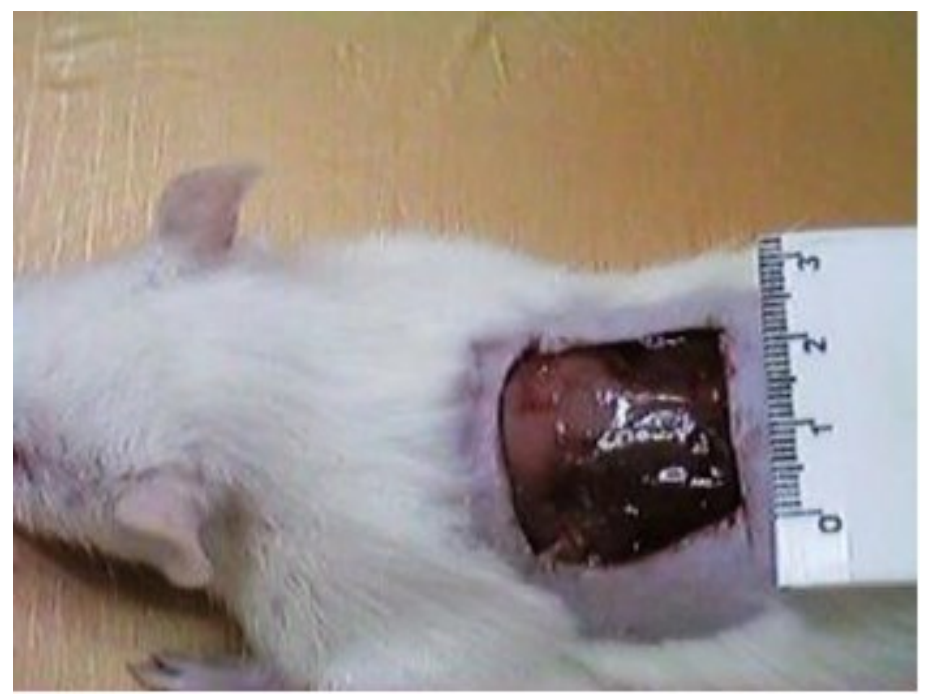

Figure 1 - Skin wound on the back of an animal.

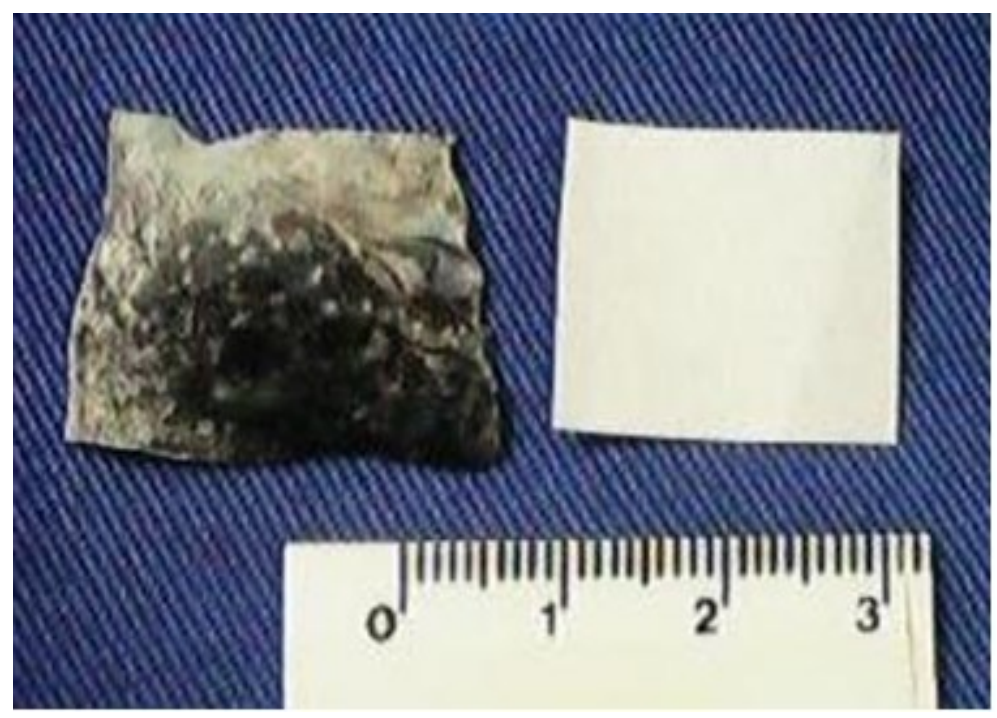

Figure 2 - Frog and mold skin segment used for marking the lesion.

In the animals of group $A$ - test $(n=10)$ a frog skin segment (Rana catesbiana) was applied over the open wound, sutured to the edge of the skin with 4 separate nylon no 0000 points (Figure 3 ). The fresh skin was washed and brushed with $0.9 \%$ saline with 3 replicates before use. 


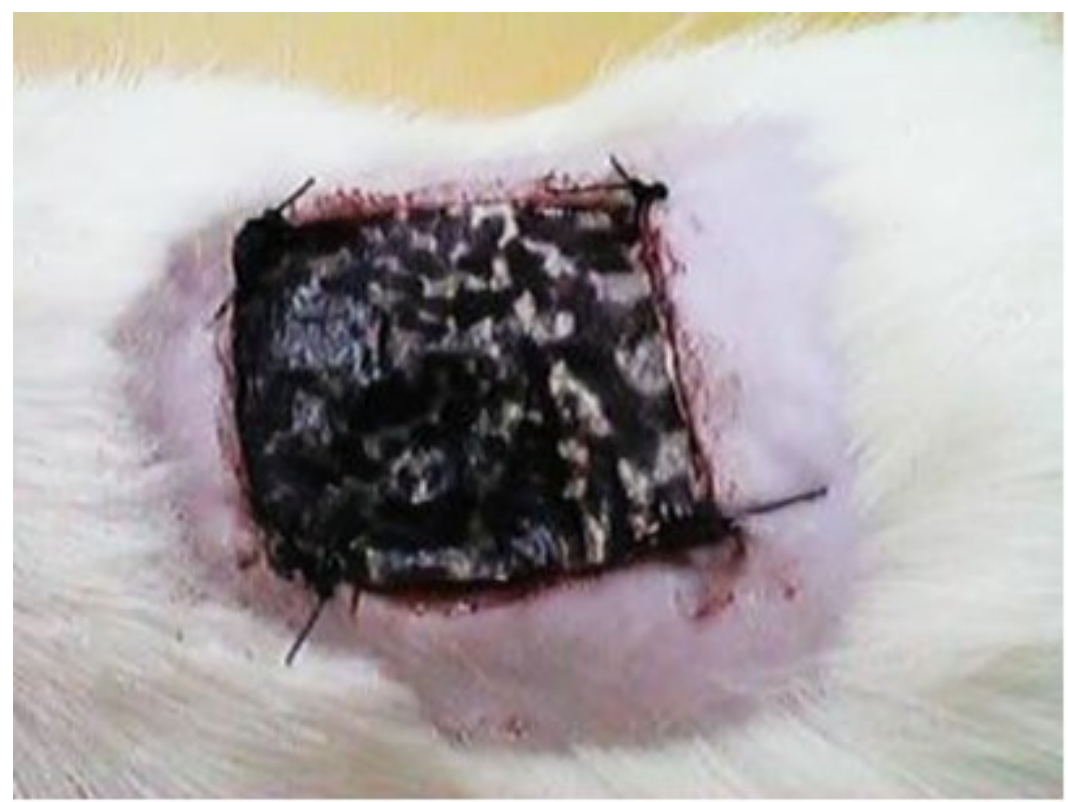

Figure 3-Rana catesbiana frog skin sutured over the open wound

Frog skins were changed once a week, until 15 days of observation were completed. In group B - control, $(n=10)$ the topical treatment was carried out in the same periods, with application of saline solution $0.9 \%, 1 \mathrm{ml}$ on each wound once a day. At the end of the observation period, the animals were anesthetized again, and $5 \mathrm{ml}$ of blood were collected per cardiac puncture for laboratory serum dosages of: alanine aminotransferase (ALT), aspartate aminotransferase (AST), urea and creatinine, in order to observe the possible toxicity of frog skin treatment for the liver and kidneys. The dosages were performed on the Biochemical Analyzer Bioplus 200, using Labtest kits (MG, Brazil).

Bromatological analysis of Rana catesbeiana skin samples was carried out using a standard technique from the Adolfo Lutz Institute-Brazil, to study their chemical, physical and bacterial composition.

The data were analyzed by Student's t-test, using BioEstat 5.0 software, considering significant the differences when $p<0.05$. 
Toxicology of skin of Rana catesbeiana as a biological dressing in skin wounds of rats

Marques JPSP, Azevedo IM, Medeiros AC

\section{RESULTS}

All animals survived the experiment and none of them developed complications at the wounds under study, such as infection and allergic reaction to the agents used. Biochemical dosages, which evaluated liver and renal function tests, are summarized in Table 1. The values of AST, ALT, urea and creatinine showed no significant difference between the means of dosing when the test and control groups were compared. The $p$ values were invariably $>0.05$. Tables 2 and 3 show bromatological analyzes of skin samples used in the study.

Table 1 - Dosagens de AST, ALT, ureia e creatinina comparando os grupos teste e controle.

\begin{tabular}{|c|c|c|c|}
\hline Variables & Group Test & Group Control & P-value \\
\hline AST(u/L) & $65.7 \pm 7.9$ & $63.7 \pm 4.62$ & 0.59 \\
\hline $\operatorname{ALT}(u / L)$ & $44.0 \pm 10.6$ & $49.7 \pm 6.7$ & 0.19 \\
\hline Urea(mg/dL) & $59.7 \pm 4.7$ & $58.4 \pm 6.5$ & 0.30 \\
\hline Creatinine(mg/dL) & $0.25 \pm 0.05$ & $0.30 \pm 1.0$ & 0.17 \\
\hline \multirow{2}{*}{\multicolumn{4}{|c|}{$\begin{array}{l}P>0.05 \text { No significant differences were observed comparing the groups studied. Data are } \\
\text { expressed as mean } \pm \text { standard deviation. } \\
\text { Table } 2 \text { - Analysis performed by the Division of Bromatology and Chemistry of the Adolfo Lutz } \\
\text { Institute- Brazil in the skin sample of Rana catesbiana used in the present study. }\end{array}$}} \\
\hline & & & \\
\hline \multicolumn{2}{|l|}{ PARAMETERS } & \multicolumn{2}{|c|}{ RESULTS } \\
\hline \multicolumn{2}{|l|}{ Reaction of sulfuric gas } & \multicolumn{2}{|c|}{ Negative } \\
\hline \multicolumn{2}{|l|}{ Microscopic Examination } & \multicolumn{2}{|c|}{ No parasits were found } \\
\hline \multicolumn{2}{|l|}{ Bacteriological examination } & \multicolumn{2}{|c|}{ Zero bacteria/g } \\
\hline \multicolumn{2}{|l|}{ Volatile substances (g\%) } & \multicolumn{2}{|c|}{79.07} \\
\hline \multicolumn{2}{|l|}{ Fixed mineral residue (g\%) } & \multicolumn{2}{|c|}{0.9} \\
\hline \multicolumn{2}{|l|}{ Lipids (g\%) } & \multicolumn{2}{|c|}{0.44} \\
\hline \multicolumn{2}{|l|}{ Protides (g\%) } & \multicolumn{2}{|c|}{19.14} \\
\hline \multicolumn{2}{|l|}{ Total percent of aminoacids (\%) } & \multicolumn{2}{|c|}{$5.67 \%$} \\
\hline
\end{tabular}


Toxicology of skin of Rana catesbeiana as a biological dressing in skin wounds of rats Marques JPSP, Azevedo IM, Medeiros AC

Table 3 - Bromatological analysis of fatty tissue extracted from the skin of Rana catesbiana.

PARAMETERS

\begin{tabular}{lc}
\hline Moisture \% & 0.40 \\
Mineral residue\% & 0.09 \\
Protein\% & Zero \\
Lipids\% & 99.48 \\
Acidity in normal solution\% & 2.62 \\
Peroxide index & 15 \\
Acidity level \% & 1.47 \\
\hline
\end{tabular}

\section{DISCUSSION}

Amphibian skin has a tissue repair and a defence system that enables wound healing without scarring ${ }^{7}$ and contains a huge arsenal of pharmacological agents, including multiple neuropeptides. All frog species synthesize a set of antimicrobial peptides (AMPs), constituting families of 2-100 closely related members ${ }^{8}$. Over the past two decades, in vitro and in vivo experiments have demonstrated that frog-skin AMPs play a crucial role in maintaining the equilibrium of the natural microbial flora and that their synthesis is induced by microorganisms ${ }^{9}$. Biological amines such as serotonin and methylated congeners occur in high concentrations in the cutaneous glands of buffoon amphibians, whereas histamine and phenolic amines have been found in other species not used in human food ${ }^{10}$.

Based on the diversity of the chemical composition of the frogs skin, the present study was carried out to examine the toxicological repercussion of this integument when used as biological dressing of the skin of rodents. This is a preliminary study, which aimed the examination of possible toxicity to the liver and renal functions. In the case of Rana catesbeiana, a species used commercially for human food, it was expected no toxic effects of its skin for vital functions in the rats used in this study. When comparing the test group (using frog skin as a biological dressing) with the control group, no significant differences were seen in the liver and kidney function tests. We did not find any recent article in literature on the possible toxicity of substances in the composition on the skin of Rana catesbiana $^{11}$. 
Toxicology of skin of Rana catesbeiana as a biological dressing in skin wounds of rats

Marques JPSP, Azevedo IM, Medeiros AC

The physicochemical composition of the cutaneous tissues of Rana catesbiana was evaluated in the Division of Bromatology of the Adolfo Lutz Institute-Brazil. The results did not mention any toxic substance and evidence of contaminants, leading to the possibility of non-toxic effects of the skin of these animals on the examined organs. In fact, our biochemical results of liver and kidney function tests showed that there were no significant difference in urea, creatinine, AST, and ALT in the frog skin rats compared to the control group. More complete further toxicological studies should be carried out from the biochemical, immunological and genotoxicity view points.

In conclusion, the skin of Rana catesbiana used as a biological dressing for open wounds of the skin of rats did not cause significant changes in the liver and kidney function tests in the animals studied.

\section{REFERENCES}

1. Asoodeh A, Zare Zardini $\mathrm{H}$, Chamani JK. Identification and characterization of two novel antimicrobial peptides, temporin-Ra and temporin-Rb, from skin secretions of the marsh frog (Rana ridibunda). Peptide Sci. 12012;8(1):10-16.

2. Gomes A, Gir, B, Saha A, Mishra R, Dasgupta SC, Debnath A. Bioactive molecules from amphibian skin: their biological activities with reference to therapeutic potentials for possible drug development. Indian J Exper Biol. 2007;45(5): 579-93.

3. Sai KP, Reddy PN, Babu M: Investigations on wound healing by using amphibian skin. Indian J Exp Biol. 1995;33:673-6.

4. Sai KP, Jagannadham MV, Vairamani M, Prasada RN, Sharada DA, Nagaraj R, Sitaram $\mathrm{N}$. Tigerinins: Novel antimicrobial peptides from the Indian frog Rana tigerina. J Biol Chem. 2001; 276:2701-7.

5. Cao X, Wang Y, Wu C, Li X, Fu Z, Yang M, Bian W, Wang S, Song Y, Tang J, Yang X. Cathelicidin-OA1, a novel antioxidant peptide identified from an amphibian, accelerates skin wound healing. Sci Rep. 2018;8(1):943-7.

6. Young PY, Khadaroo RG. Surgical site infections. Surg Clin North Am. 2014;94(6):124564.

7. Haslam IS, Roubos EW, Mangoni ML, Yoshizato K, Vaudry H, Kloepper JE. From frog integument to human skin: dermatological perspectives from frog skin biology. Biol Rev Camb Philos Soc. 2014;89: 618-55. 
8. Mangoni ML. Temporins, anti-infective peptides with expanding properties. Cell Mol Life Sci. 2006;63:1060-9.

9. Mangoni ML, Miele R, Renda TG, Barra D, Simmaco M. The synthesis of antimicrobial peptides in the skin of Rana esculenta is stimulated by microorganisms. FASEB J. 2001;15:1431-2.

10. Daly JW, Gusovsky F, et al. First occurence of tetrodotoxin in a dendrobatic frog, with furter reports for the bufonid genus Atelopus. Toxicon. 1994;32:279-85.

11. Bonatto CC, Joanitti GA, Silva LP. In vitro cytotoxic activity of chitosan-bullfrog oil microemulsion against melanoma cells. IET Nanobiotechnol. 2015;9(4):172-7. 